\title{
Seasonal development of invertebrate zooplankton on Flemish Cap
}

\author{
John T. Anderson \\ Department of Fisheries and Oceans, Science Branch, PO Box 5667, St. John's, Newfoundland, Canada A1C 5X1
}

\begin{abstract}
Flemish Cap was dominated by the calanoid copepod Calanus finmarchicus. It constituted 37 to $69 \%$ of all zooplankton sampled with coarse mesh nets $(0.333$ and $0.505 \mathrm{~mm})$ and 15 to $33 \%$ in fine mesh nets $(0.165 \mathrm{~mm})$ during March to August. Owing to its large size, C. finmarchicus dominated the biomass of all species sampled in both coarse and fine mesh samples. The dominant copepod species in fine mesh samples $(0.165 \mathrm{~mm})$ were Oithona similis and $O$. atlantica which together comprised 20 to $42 \%$ of all species sampled. C. finmarchicus formed a discrete population on Flemish Cap with peak spawning in mid-April, beginning first in waters $\leq 200 \mathrm{~m}$ depth. Peak biomass occurred in late May and probably early June coincident with peak abundance of late-stage copepodites. Significant differences were observed in the rate of $C$. finmarchicus development and absolute abundance among years sampled on Flemish Cap. Differences in development were related to differences in the seasonal heating of surface waters on Flemish Cap in different years. It is hypothesized that these differences in rate of development and absolute abundance of $C$. finmarchicus and other copepods will have a significant effect on larval fish feeding, growth and survival.
\end{abstract}

\section{INTRODUCTION}

Interannual differences in food availability for larval fish stages are believed to be an important determinant of their survival and ultimate recruitment to adult populations. Several hypotheses relate food availability to larval fish survival under varying conditions (Anderson 1988). Food availability has been related to variable timing of the spring bloom in relation to fish spawning, varying food concentration at the pycnocline in relation to storm mixing and to changes in the magnitude of spring production. Emphasis has focused on the importance of the classical marine food chain, consisting of relatively large phytoplankton and herbivores, to fisheries production in temperate stratified and upwelling systems (Cushing 1989). Recently, the role and response of copepods in such systems have been hypothesized to be a direct link in certain circumstances between varying environmental events effecting survival of larval fish and, by inference, fish recruitment (Runge 1988).

The purpose of this paper is to describe the invertebrate zooplankton community on Flemish Cap $\left(47^{\circ} \mathrm{N}\right.$, $45^{\circ} \mathrm{W}$ ), and to evaluate how the dynamics of dominant community components may influence fish recruitment in the region; particularly interannual differences in the seasonal timing of copepod spawning and development. Flemish Cap is an offshore bank historically fished for cod and redfish, although at present redfish is dominant. For several years it was the focus of an international study examining possible causes of recruitment variability in these fishes (Lilly 1987). Extrusion of redfish larvae peaks during April; this species constitutes $90 \%$, or more, of all ichthyoplankton from March to August (Anderson 1984). Redfish larvae feed predominantly on eggs and nauplii stages of calanoid copepods (Bainbridge \& McKay 1968) and, therefore, are highly dependent on the spring production of copepods. In such a system copepods are expected to have a direct effect on larval fish survival (Runge 1988).

Previous studies of invertebrate zooplankton on Flemish Cap have been carried out during the period from February to September and spanning the years 1958 to 1981 (Vladimirskaya 1967, Konstantinov et al. 1985). However, these studies have been limited by the use of a coarse mesh net (ca $0.5 \mathrm{~mm}$ ), irregular sampling, contradictory results and lack of comparison of interannual variability. Nevertheless, they have described the general zooplankton community on Flemish Cap, including the time of spring spawning and peak biomass. 


\section{MATERIALS AND METHODS}

Field collections. Zooplankton was collected during 14 plankton surveys between 1977 and 1983 on Flemish Cap (Fig. 1). Each survey lasted 3 to $7 \mathrm{~d}$ and comprised 20 to 56 stations spaced 20 nautical miles (37 km) apart in a grid-like pattern. During 1978 to 1983 sampling dates ranged from the beginning of March to the first week of August, with 1 survey conducted in October 1977 (Table 1).

Plankton samples were collected at each station using a $61 \mathrm{~cm}$ bongo sampler with two $0.333 \mathrm{~mm}$ mesh nets. In 2 cruises $0.505 \mathrm{~mm}$ mesh nets were used although this was limited to one side of the bongo sampler during the cruise 25 to 30 Oct 1977 and 31 stations during the cruise 2 to 9 May 1981. During 7 cruises a $20 \mathrm{~cm}$ bongo sampler was used simultaneously with the $61 \mathrm{~cm}$ bongo sampler, using 0.165 and $0.253 \mathrm{~mm}$ mesh nets. Finally, a $50 \mathrm{~cm}$ ring net using a $0.080 \mathrm{~mm}$ mesh net was used during 4 cruises. A summary of the number of stations sampled and samples processed for species identifications and plankton biomass is given in Table 1 .

The bongos were towed obliquely from near the bottom or $200 \mathrm{~m}$ depth, whichever was less, at ca 1.25 to $1.5 \mathrm{~m} \mathrm{~s}^{-1}$ (2.5-3.0 knots), following standard techniques of Smith \& Richardson (1977). Payout and retrieval rates were 0.83 and $0.33 \mathrm{~m} \mathrm{~s}^{-1}$, respectively. Each net was fitted with a GO flow meter and maximum depth was monitored using a pressure sensor

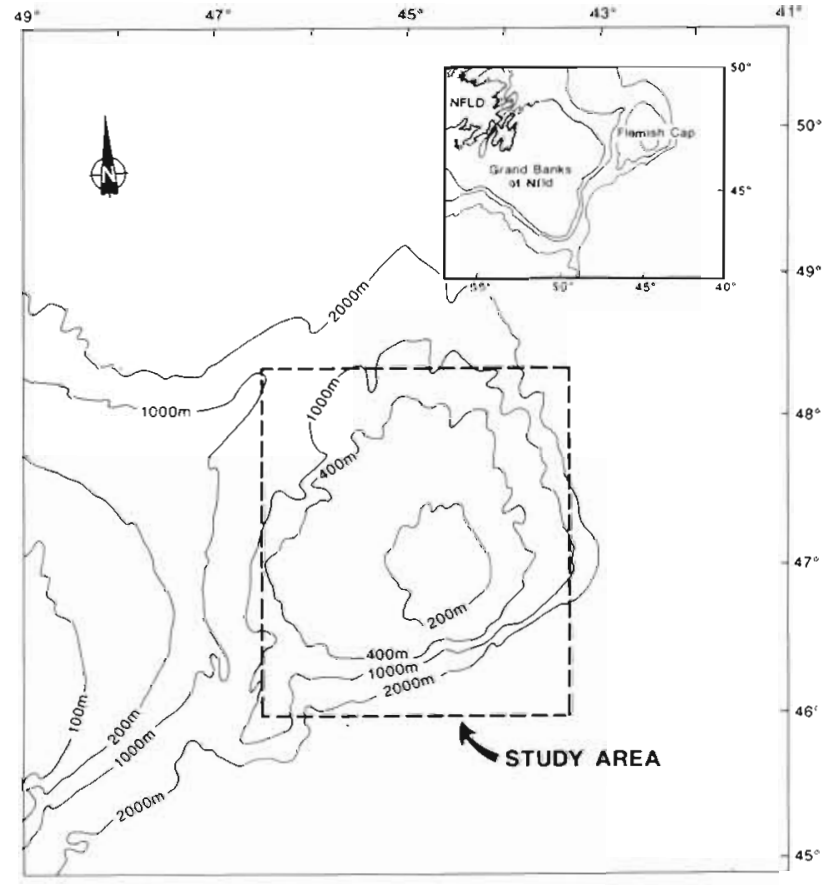

Fig. 1. Flemish Cap $\left(47^{\circ} \mathrm{N}, 45^{\circ} \mathrm{W}\right)$, situated west of the Grand Bank of Newfoundland bounded by the area sampled

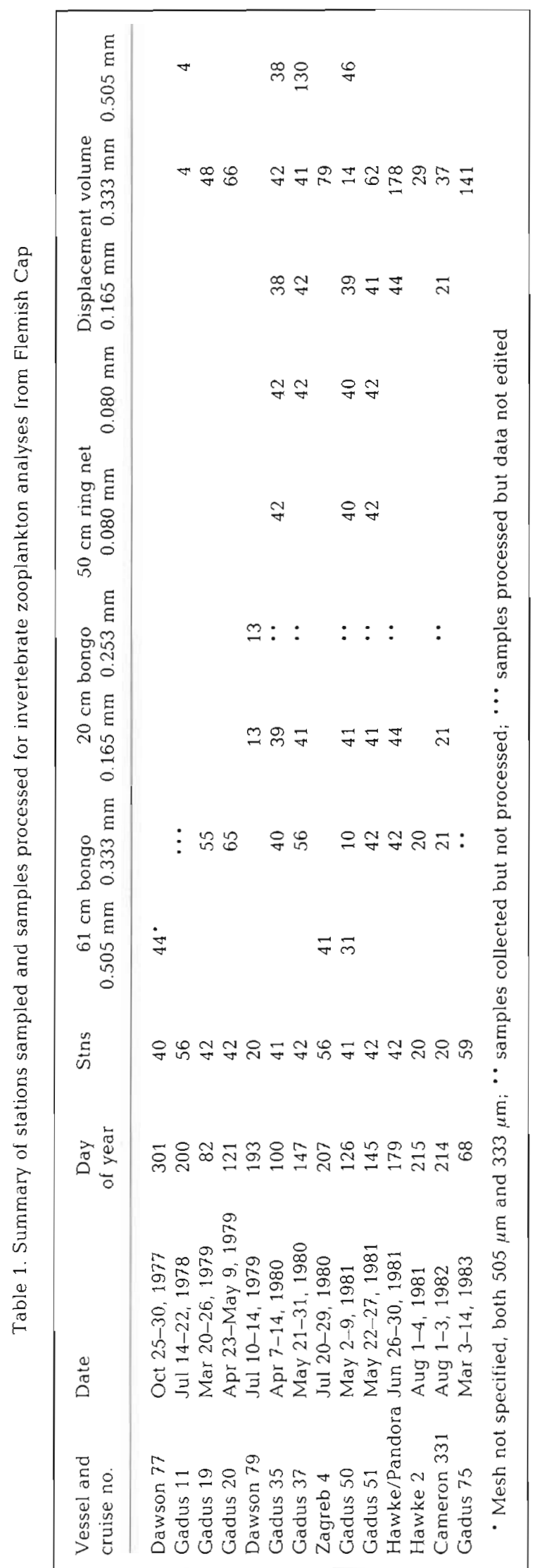


fitted above the bongo frame. During 2 surveys, 20 to 26 Mar and 10 to 14 Jul 1979, oblique tows were done to $125 \mathrm{~m}$ depth only. Ring net samples were towed vertically from $100 \mathrm{~m}$ depth. All samples were preserved in $5 \%$ buffered formalin.

Tow data from the 14 cruises were edited to remove identifiable sources of error. Editing for volume of water filtered was based on a comparison of least squares regressions of water volume versus tow time for the cruise data compared to the modelled relationship $Y=29.91 X$ (Webster \& Anderson 1987), where $Y$ = water volume $\left(\mathrm{m}^{3}\right) ; \mathrm{X}=$ tow time $(\mathrm{min})$. Tow depth was edited based on the regression of tow depth versus edited water volume data compared to the modelled relationship $Y=0.335 X$, where $Y=$ tow depth; $X=$ water volume. In each case outliers were corrected if possible based on verification of incorrect data recording or coding. There were few cases of low water volume filtered, indicating that clogging of the nets was not a problem. If water volume was missing for a particular sample then water volume was estimated based on the relevant regression equation for that cruise.

Laboratory processing. Plankton volume was measured using methods similar to those outlined by Smith \& Richardson (1977). Large fish and gelatinous zooplankton $\left(>1 \mathrm{~cm}^{3}\right)$ were removed from the sample prior to measurement, usually by use of a coarse mesh net. The remaining sample was then drained using Nitex mesh of the same, or smaller, size as the original sample until drainage diminished to the occasional drop. Plankton volume to the nearest $\mathrm{ml}$ was then measured by displacement of water in a graduated cylinder.

All large animals (e.g. chaetognaths, ctenophores, cnidarians, amphipods, decapods, mysis, larvaceans, euphausiids, fish, ostracods, pteropods, polychaetes) were initially removed and identified to species, if possible, and counted. For large mesh samples $(0.505$ and $0.333 \mathrm{~mm}$ mesh, $61 \mathrm{~cm}$ bongo) samples were split using either Folsom or Motoda plankton splitters or the beaker technique of Van Guelpen et al. (1982), and ca 100 individuals of the dominant taxon were identified and counted from the subsample. Less numerous taxa were counted from progressively larger subsamples. For samples from 0.165 and $0.080 \mathrm{~mm}$ mesh nets, total sample volume was made up to a known amount and $1.0 \mathrm{ml}$ subsamples were withdrawn. For all samples at least 300 individuals were identified and counted, where ca 100 individuals of the most common taxon were identified. When one species completely dominated the sample, counting was continued to ensure that 30 to 50 of the next most abundant taxa were identified and counted. Taxa were identified as completely as possible using available literature, and abundant copepod species were staged where possible.

All data were coded according to the method of Foy \& Anderson (1986) and extensively edited. All data base management and statistical analyses were done using the Statistical Analysis System (SAS 1985). Abundance (number $\mathrm{m}^{-2}$ ) was calculated as

$$
N=\frac{C D}{\Pi r^{2} L}
$$

and density (number $\mathrm{m}^{-3}$ ) was calculated as

$$
\mathrm{N}^{\prime}=\frac{\mathrm{C}}{\Pi \mathrm{r}^{2} \mathrm{~L}}
$$

where $\mathrm{C}=$ number of plankton collected; $\mathrm{D}=$ maximum sampled depth $(\mathrm{m}) ; \mathrm{L}=$ length of the tow path $(\mathrm{m}) ; \mathrm{r}=$ radius of the net opening $\left(\mathrm{m}^{2}\right)$.

Statistical analyses for abundance differences were done using parametric techniques on square root transformed data whenever possible. The assumption of homogeneity of variances was tested for t-test comparisons using the F-ratio test and for multiple mean comparisons using either Bartlett's chi-square test or Levene's test (Brown \& Forsythe 1974). When the assumption of homogeneity was rejected non-parametric techniques were used. For comparison between 2 means Wilcoxon's test was used (Sokal \& Rohlf 1969). For comparison of more than 2 means tests for differences were done using a standard unbalanced ANOVA on ranked scores of the original data (SAS 1985). The ANOVA on ranked scores is considered to be a more robust analysis than the Kruskal-Wallis test with the advantage that the ranked data can be analyzed using a posteriori techniques routinely available for parametric analyses. In all cases Duncans's multiple range test was used testing for differences at $p<0.05$. For comparisons of relative stage frequency differences of copepods the Kolmogorov-Smirnov test was used (Siegel 1956).

Estimates of copepod development. Development times of zooplankton are directly dependent on water temperature in which the zooplankton are developing. Predictions of stage duration and peak spawning of Calanus finmarchicus were based on the temperature dependent Bělehrádek equations of Corkett et al. (1986) which are of the general form

$$
\mathrm{D}=\mathrm{a}(\mathrm{T}-\alpha)^{\mathrm{b}}
$$

where $\mathrm{D}=$ development time $(\mathrm{d})_{i} \mathrm{~T}=$ temperature $\left({ }^{\circ} \mathrm{C}\right) ; \mathrm{a}, \alpha$ and $\mathrm{b}=$ fitted parameters. The a parameter is for $C$. finmarchicus copepodite stages: $\mathrm{CI}=6419$, C II $=8014, \mathrm{CIII}=9816, \mathrm{CIV}=11601, \mathrm{CV}=13526$ and $\mathrm{CVI}=17477$. For all equations $\alpha=-10.60, \mathrm{~b}=-2.05$. 
Backcalculations of stage development to estimate peak spawning of Calanus finmarchicus for 1980 and 1981 were based on observations during the last week of May each year. In 1980 copepodite stage CIII dominated, in 1981 stage CIV. Development times for stages CIII and CIV were based on average may temperatures. For stage CII copepodites predictions were based on a weighted average of April and May temperatures, where April temperatures were weighted by a factor of 2. Finally, estimates for stage CI were based on average April temperatures as all development was estimated to have occurred during this month. It is assumed that early stages of marine copepods, and specifically $C$. finmarchicus, occur in the upper water column (Krause \& Trahms 1982, Williams et al. 1987, Williams \& Conway 1988). Therefore, estimates of development rate were based on surface water temperatures. Average monthly temperature at $10 \mathrm{~m}$ depth was estimated from Nansen bottle and bathythermograph data available from the Marine Environmental Data Service, Ottawa (MEDS). The area chosen to be $\leq 200 \mathrm{~m}$ depth was bounded by $46^{\circ} 40^{\prime}$ to $47^{\circ} 20^{\prime} \mathrm{N}$ and $44^{\circ} 30^{\prime}$ to $45^{\circ} 20^{\prime} \mathrm{W}$.

\section{RESULTS}

\section{Zooplankton biomass}

Plankton volumes are a measure of total biomass of the plankton community on Flemish Cap. A composite plot of data collected during 12 cruises in different years demonstrates that highest biomass of the mesoplankton $(0.333 \mathrm{~mm}$ mesh nets) occurred around the end of May to the beginning of June (Fig. 2a). Overall, values ranged from $0.19 \mathrm{ml} \mathrm{m}^{-3}$ in late March, prior to spring spawning of copepods, to a peak value of $0.62 \mathrm{ml} \mathrm{m}^{-3}$ during late May 1981. Values generally decreased by late July and early August.

Plankton biomass measured from $0.165 \mathrm{~mm}$ mesh samples from 6 cruises also indicated highest biomass during late May (Fig. 2b). The only July observation was in 1982 and plankton biomass was relatively high compared to observations earlier in the year for 1980 and 1981. This was similar to the high 1982 July plankton biomass as measured by the larger $0.333 \mathrm{~mm}$ mesh samples.

Plankton biomass data for $0.080 \mathrm{~mm}$ mesh samples was only available for 2 cruises in 1980 and 2 cruises in 1981 (Fig. 2c). Plankton biomass decreased from early to late May in 1981, in contrast to plankton volume measured by coarser meshed nets. This decrease may have represented the declining biomass of copepod eggs and nauplii stages following peak spawning, as sampled by the $0.080 \mathrm{~mm}$ mesh nets.

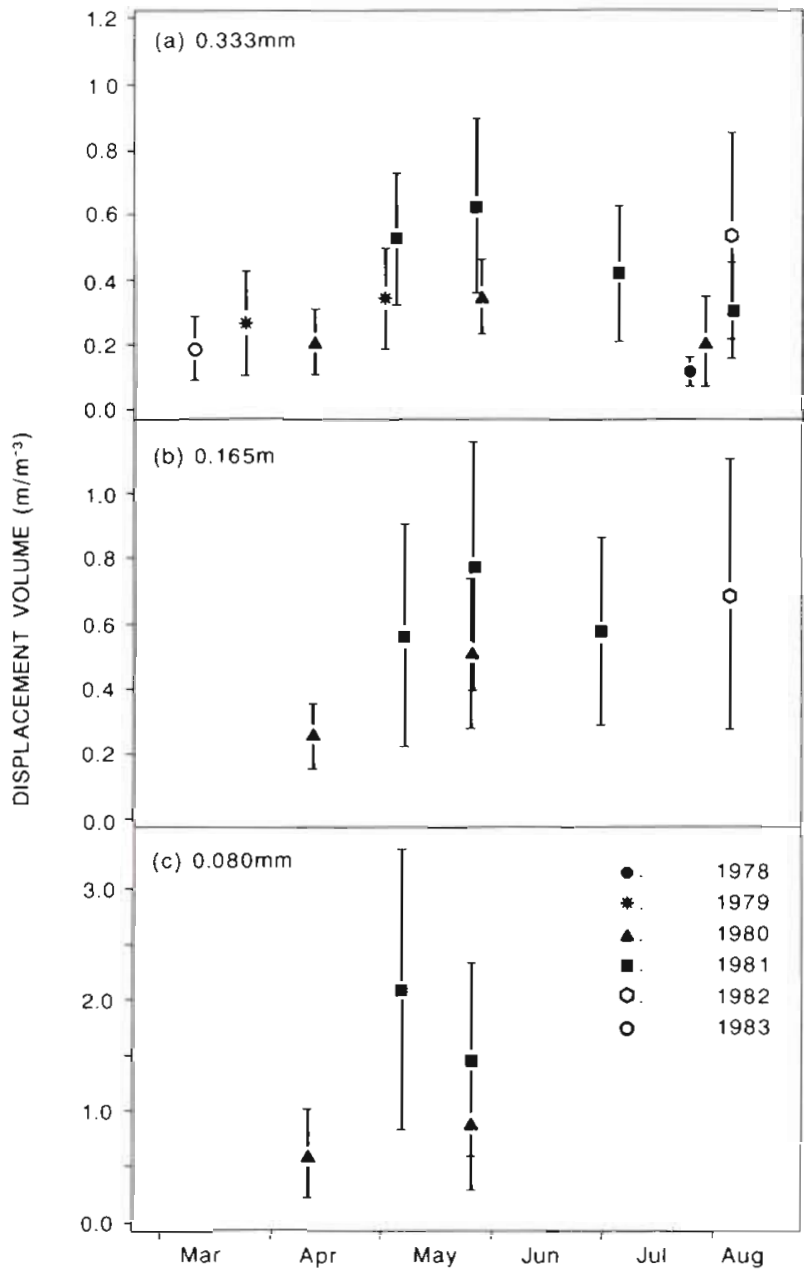

Fig. 2. Seasonal changes in plankton volume $\left(\mathrm{ml} \mathrm{m}^{-3}\right)$ of invertebrate zooplankton on Flemish Cap. Composite of data collected in different years from different mesh samples: (a) $0.333 \mathrm{~mm}$ mesh, (b) $0.165 \mathrm{~mm}$ mesh, (c) $0.080 \mathrm{~mm}$ mesh. Bars: 1 SD about cruise means

\section{Zooplankton community}

Calanoid copepods, in particular Calanus finmarchicus, dominated the invertebrate zooplankton community on Flemish Cap (Fig. 3). Data collected by the $0.333 \mathrm{~mm}$ mesh $61 \mathrm{~cm}$ bongo samples at different times during 1977 to 1982 are plotted as a composite in Fig. 3 to represent general conditions during different seasons on Flemish Cap. During late March total copepods accounted for approximately $50 \%$ of the zooplankton. By early August copepods constituted more than $90 \%$ of total zooplankton, declining to about $70 \%$ by the end of October. At all times the dominant species was C. finmarchicus, which made up from 37 to $69 \%$ of all zooplankton sampled. This percentage steadily increased from March to August. There was some variation in relative abundance among years. For example, C. finmarchicus represented $67 \%$ of the total zoo- 


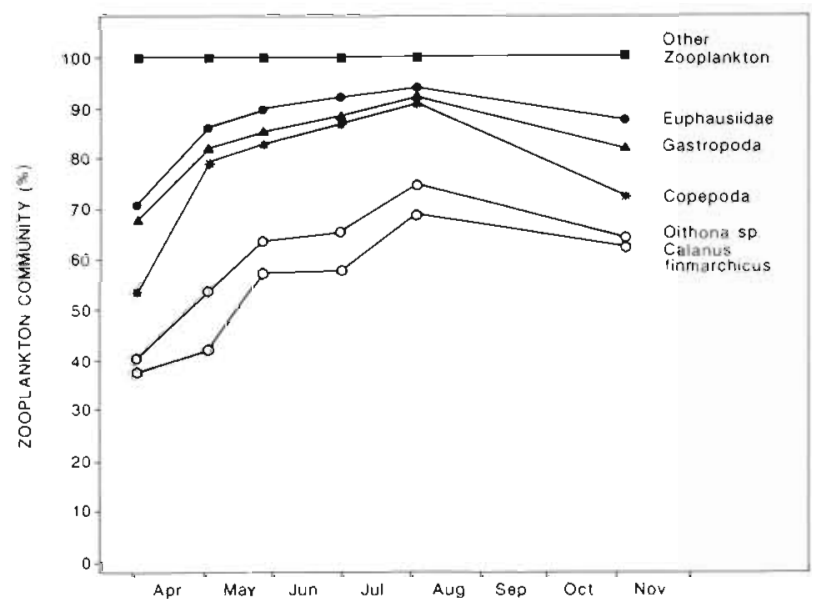

Fig. 3. Seasonal changes in percent community composition of invertebrate zooplankton on Flemish Cap broken down by selected groups. Composite picture of data collected in different years from $0.333 \mathrm{~mm}$ mesh samples

plankton 1 to 4 August 1981 and $83 \% 1$ to 3 August 1982. Other medium-sized copepods ( 2.0 to $5.5 \mathrm{~mm} \mathrm{TL}$ ) that occurred abundantly were Metridia lucens, $M$. longa and $C$. glacialis. The large calanoid copepods (5.0 to $10 \mathrm{~mm} \mathrm{TL}), C$. hyperboreus and Euchaeta norvegica, were observed in small numbers.

Non-copepod species groups represented in the collections were summarized into 12 species groups. In each case 1 or 2 species dominated within each group. The ostracods were dominated by Conchoecia elegans and $C$. obtusata, gastropods by Limacina sp., larvaceans by Oikopleura vanhoeffeni and O. labradoriensis, and euphausiids by Meganictyphanes norvegica. Other species groups occurring in low relative densities included echinoderm larvae, hyperiid amphipods, chaetognaths (Sagitta spp.), ctenophors (Pleurobrachia spp.), jellyfish (Cnidaria) and polychaetes. The species groups summarized here as 'other' ranged from 9 to $30 \%$ abundance of all species observed (Fig. 3).

Samples of smaller zooplankton from finer mesh samples $(0.165 \mathrm{~mm}$ mesh, $20 \mathrm{~cm}$ bongos) again indicated that copepods numerically dominated the zooplankton community, ranging from 55 to $82 \%$ during the period April through July (Fig. 4). The dominant species in these samples were the cyclopoid copepods Oithona similis and $O$. atlantica. Together they comprised from 20 to $42 \%$ of all species sampled by the finer mesh nets, and 37 to $51 \%$ of all copepods. Calanus finmarchicus numerically represented 15 to $43 \%$ of all species sampled. Similar to samples from the coarser mesh nets $(0.333 \mathrm{~mm})$ there was an increase in the percent composition of copepods during the period sampled from early April to early August. Other species of small copepods ( 0.5 to $1.5 \mathrm{~mm}$ TL) present in these samples were Microcalanus pygmaeus, which was very similar in abundance to $O$. atlantica, followed by Pseudocalanus spp., Scolecithricella minor and Oncaea borealis, in descending order of abundance.

A comparison of abundances of Calanus finmarchicus and Oithona spp. collected with $0.165 \mathrm{~mm}$ mesh nets shows that Oithona spp. were more numerous in 5 of 7 cruises (Table 2). In early April 1980 densities were equal for the Flemish Cap area and during 1 to 3 August 1982 densities of Oithona spp. were lower than C. finmarchicus. At other times, representing the period from May to July, Oithona spp. were 1.1 to 2.5 times more abundant than $C$. finmarchicus. When comparing biomass, however, $C$. finmarchicus dominated in all 7 cruises ranging from 8 to 137 times more in total weight (Table 2). The largest differences in total biomass occurred during early April and early August when abundances of $C$. finmarchicus were equal to or greater than those of Oithona spp., the former dominated by copepodite stages CVI and CV, respectively.

A second notable difference in the finer mesh samples was the abundance of foraminiferans and radiolarians, of which Globigerina spp. were the dominant species identified. Together these protists accounted for 10 to $43 \%$ of zooplankton enumerated.

\section{Timing of annual copepod spawning on Flemish Cap}

$$
\text { Eggs and nauplii data }
$$

Copepod spawning on Flemish Cap was examined first based on early copepod stages sampled by the fine mesh nets $(0.080 \mathrm{~mm})$ in 1980 and 1981 . To compare spatial differences of spawning in waters on and around the Cap, egg and nauplii data were divided into 3 depth strata according to bottom topography: $\leq 200$, 201 to 400 and $>400 \mathrm{~m}$ water depth.

Copepod spawning was most concentrated in the shallowest waters overlying Flemish Cap. This is sup-

Table 2. Ratios of Calanus finmarchicus mean density (no. $\left.\mathrm{m}^{-3}\right)$ and weight $\left(\mathrm{mg} \mathrm{m}^{-3}\right)$ to Oithona spp. at different times. Data for Flemish Cap from small mesh samples $(0.165 \mathrm{~mm})$. Weights were estimated by the sum of total weight in each copepodite stage for each species for each cruise, standardized for the numbers of stations in each cruise. Copepodite weights from Tremblay (1981)

\begin{tabular}{|lcr|}
\hline Date & Density & Weight \\
\hline Apr 7-14, 1980 & $1.01: 1$ & $137: 1$ \\
May 2-9, 1981 & $0.52: 1$ & $8: 1$ \\
May 22-27, 1981 & $0.53: 1$ & $23: 1$ \\
May 21-31, 1980 & $0.88: 1$ & $39: 1$ \\
Jun 26-30, 1981 & $0.40: 1$ & $29: 1$ \\
Jul 10-14, 1979 & $0.47: 1$ & $34: 1$ \\
Aug 1-3, 1982 & $1.23: 1$ & $78: 1$ \\
\hline
\end{tabular}


ported by highest densities of eggs and nauplii in waters $\leq 200 \mathrm{~m}$ depth during the 2 earliest cruises, 7 to 14 April 1980 and 2 to 9 May 1981 (Table 3). During these 2 cruises, however, nauplii densities were lowest in the 201 to $400 \mathrm{~m}$ depth strata and higher again in deeper waters. Therefore, spawning may have occurred both over central Flemish Cap and in deep oceanic waters surrounding the Cap. The mean egg and nauplii densities among strata for these cruises were not significantly different.

In late May $1980 \mathrm{egg}$ densities were highest in the 201 to $400 \mathrm{~m}$ depth stratum and lowest in deep oceanic waters surrounding Flemish Cap (Table 3). In late May 1981, egg densities were still highest in waters $\leq 200 \mathrm{~m}$ depth. Nauplii densities were similar in all depth strata during late May 1980 and lowest in 201 to $400 \mathrm{~m}$ depth waters in late May 1981. Comparison of mean densities among strata demonstrated no significant differences during 21 to 31 May 1980. However, during 22 to 27 May 1981 eggs were significantly different among strata, being highest over central Flemish Cap $\leq 200 \mathrm{~m}$ depth $(p=0.0650)$ and nauplii were significantly more abundant in waters $>400 \mathrm{~m}$ depth $(\mathrm{p}=0.0439)$.

The decrease in egg densities for waters $\leq 200 \mathrm{~m}$ water column depth from early April to late May demonstrates that peak calanoid spawning occurred sometime during mid to late April. Nauplii data support this observation. Densities were low during the first week of April 1980, averaging only 183 nauplii $\mathrm{m}^{-3}$ in waters $\leq 200 \mathrm{~m}$ depth. By the first week of May 1981 densities increased to 1226 nauplii $\mathrm{m}^{-3}$ (Table 3). Together these data support the observation that copepod spawning had recently started during early April and peaked before the beginning of May.

These observations are for copepod eggs collectively and represent a composite of seasonal changes from data collected in 2 different years. Nevertheless, the general pattern of copepod spring spawning is well represented and particularly for the dominant copepod Calanus finmarchicus. Therefore, it appears spawning began first and most intensively in shallow waters $\leq 200 \mathrm{~m}$ depth overlying central Flemish Cap during the early part of April. By early May egg densities had decreased and nauplii densities increased indicating peak spawning had passed. By late May copepod spawning continued to remain high in shallow waters but may have spread to deeper waters in the 201 to 400 m depth strata. In deep oceanic waters surrounding the Cap spawning also occurred and it was often higher than that in the 201 to $400 \mathrm{~m}$ depth strata. However, egg densities in waters $>400 \mathrm{~m}$ depth never exceeded those over central Flemish Cap ( $\leq 200 \mathrm{~m}$ depth).

\section{Calanus finmarchicus data}

The progression of copepod spawning and spring production is examined here further based on copepodite stages of Calanus finmarchicus as sampled by $0.165 \mathrm{~mm}$ mesh nets and occurring at $\leq 400 \mathrm{~m}$ depth on

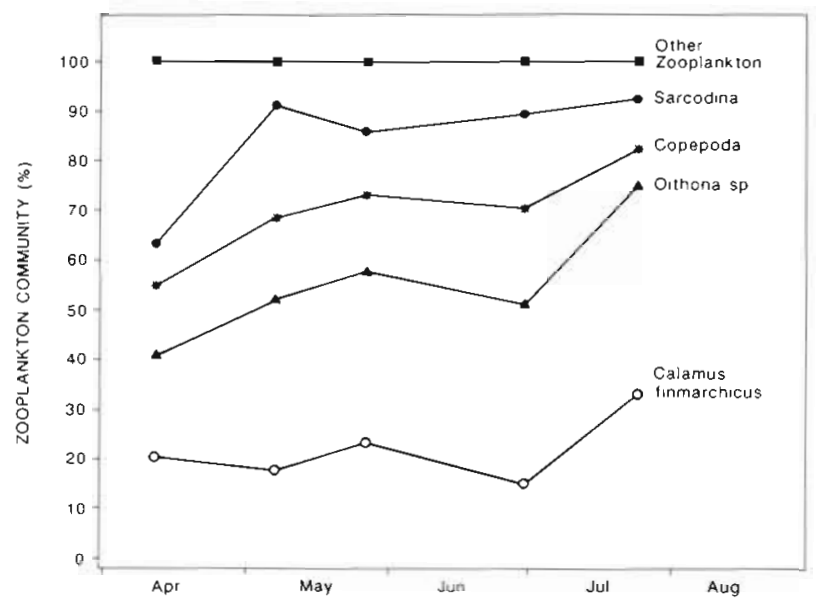

Fig. 4. Seasonal changes in percent community composition of invertebrate zooplankton on Flemish Cap broken down by selected groups. Composite picture of data collected in different years from $0.165 \mathrm{~mm}$ mesh samples

Table 3. Copepod egg and nauplii mean densities (no. $\mathrm{m}^{-3}$ ) sampled on Flemish Cap within different strata from $0.080 \mathrm{~mm}$ mesh samples

\begin{tabular}{|llrrrr}
\hline \multirow{2}{*}{ Date } & Stage & \multicolumn{2}{c}{ Bottom depths (m) } \\
& & $\leq 200$ & $201-400$ & $\leq 400$ & $>400$ \\
\hline \multirow{2}{*}{ Apr 7-14, 1980 } & Eggs & 2315 & 1985 & 2059 & 1012 \\
& Nauplii & 183 & 74 & 99 & 106 \\
May 2-9, 1981 & Eggs & 1335 & 286 & 519 & 321 \\
May 20-26, 1980 & Nauplii & 1226 & 821 & 912 & 1069 \\
May 22-27, 1981 & Eggs & 736 & 531 & 545 & 522 \\
& Nauplii & 490 & 1000 & 287 & 448 \\
& Eggs & 633 & 1049 & 1130 & 308 \\
& Nauplii & 1398 & & 1429 \\
\hline
\end{tabular}


Flemish Cap. During the cruise 7 to 14 April 1980, only stage CVI C. finmarchicus copepodites were observed in any significant abundance, supporting the observation that spawning was probably underway at that time (Fig. 5). Chronologically 25 d later, during 2 to 9 May 1981, C. finmarchicus copepodites were dominated by stages CII and CIII, with peak densities of 128 and 161 $\mathrm{m}^{-3}$, respectively. By late May 1981 (Day 145) stage CIV was clearly dominant at densities of $172 \mathrm{~m}^{-3}$ although stage $C V$ were now appearing in greater numbers with densities averaging $83 \mathrm{~m}^{-3}$. By late June 1981 stage $C V$ was now dominant with density averaging $96 \mathrm{~m}^{-3}$. Stage CV continued to dominate in subsequent cruises through July, averaging $270 \mathrm{~m}^{-3}$ during 10 to 14 July 1979 and $362 \mathrm{~m}^{-3} 1$ to 3 August 1982 .

Comparison of Calanus finmarchicus copepodite densities among the 3 depth strata support the observations from egg and nauplii data that spawning was most concentrated in the shallow waters overlying Flemish Cap. During 7 to 14 April 1980 stage CVI dominated in all 3 depth strata and was most abundant in waters $\leq 200 \mathrm{~m}$ depth, averaging $99 \mathrm{~m}^{-3}$ compared to $54 \mathrm{~m}^{-3}$ in the 201 to $400 \mathrm{~m}$ stratum, and $42 \mathrm{~m}^{-3}$ in
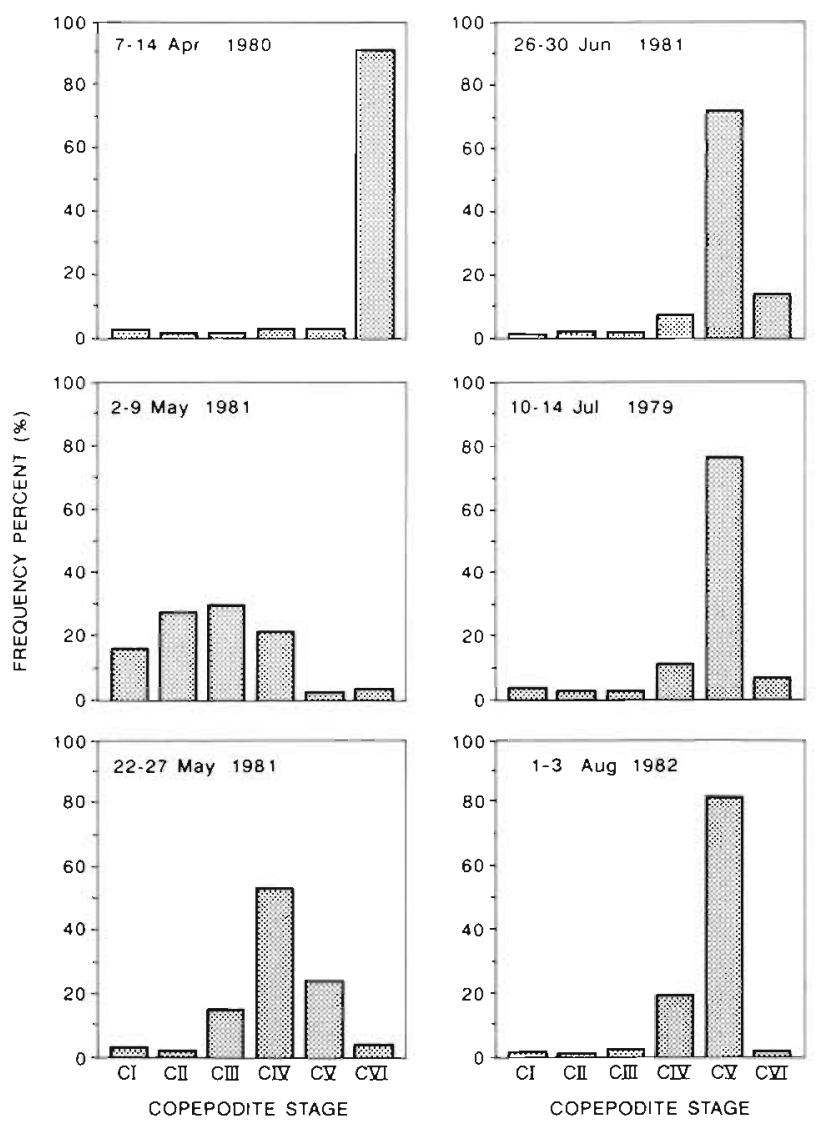

Fig. 5. Calanus finmarchicus. Seasonal changes in the percent composition of copepodite stages on Flemish Cap in waters $\leq$ $400 \mathrm{~m}$ depth. Composite picture of data collected in different years from $0.165 \mathrm{~mm}$ mesh samples waters $>400 \mathrm{~m}$ depth. Twenty-five days later during 2 to 9 May 1981 stages CIII and CIV dominated in waters $\leq 200 \mathrm{~m}$ depth, while stages CII and CIII dominated within the 201 to $400 \mathrm{~m}$ depth stratum and stage CIII dominated over deep waters $>400 \mathrm{~m}$ depth. This indicates copepodite development was more advanced over the shallow, central waters and lagged by approximately 1 development stage within the other strata. The more rapid development observed at $\leq 200 \mathrm{~m}$ depth could be the result of both an earlier start of spawning or warmer temperatures found in the central waters.

Surveys later in the year during late May 1980 and 1981, late June 1981 and July 1979 and August 1982 (using $0.165 \mathrm{~mm}$ mesh samples) demonstrated that stage CV dominated throughout all 3 depth strata. Therefore, differences in relative stage abundances among depth strata observed earlier in the year had disappeared by the end of May. However, copepodite densities of this dominant stage were always highest in waters $\leq 400 \mathrm{~m}$ depth indicating higher concentrations over Flemish Cap.

\section{Interannual differences}

There were significant differences in plankton biomass among years at all times for which direct comparisons could be made. Plankton volume measured from $0.333 \mathrm{~mm}$ mesh samples in 1980 was significantly lower $(p<0.05)$ than in 1981, during late May and in late July and early August (Fig. 2a). Plankton biomass for both 0.080 and $0.165 \mathrm{~mm}$ mesh samples was also significantly different during late May 1980 and 1981 (Fig. 2b, p<0.05). In addition, biomass during 23 April to 9 May 1979 was significantly lower than during 2 to 9 May 1981 for waters $\leq 400 \mathrm{~m}$ depth, demonstrating that plankton biomass in 1981 was relatively high compared to 1979 and 1980 ( $\mathrm{p}<0.00001$ ).

Mean plankton biomasses from $0.333 \mathrm{~mm}$ mesh samples for mid-July to the first week of August during 4 yr ranged widely, from $0.12 \mathrm{ml} \mathrm{m}^{-3}$ in 1978 to $0.53 \mathrm{ml}$ $\mathrm{m}^{-3}$ in 1982 (Fig. 2a). Only 4 observations were available for July 1978 and there are no plankton volumes from 1979. Comparison of differences among years for waters $\leq 400 \mathrm{~m}$ depth demonstrated that biomasses for 1 to 3 August 1982 were significantly higher $(\mathrm{p}<0.0001)$ than for 1 to 4 August 1981 and 20 to 29 July 1980 , which were not significantly different from each other. For waters $>400 \mathrm{~m}$ depth, 1982 was still the highest $(p=0.0275)$ year and there was no difference between 1981 and 1980 .

Samples taken in late May 1980 and 1981 with the $0.080 \mathrm{~mm}$ mesh net provide the only direct comparison of copepod eggs and nauplii. Eggs were more abun- 
dant and nauplii were less abundant in late May 1980 than in 1981. For waters over Flemish Cap $\leq 400 \mathrm{~m}$ depth, egg: nauplii ratios were 1.81:1 in 1980 compared to $0.25: 1$ in 1981 . Eggs were significantly more abundant in waters $\leq 400 \mathrm{~m}$ depth in 1980 versus $1981(\mathrm{p}=$ 0.0154 ) whereas there was no significant difference in waters $>400 \mathrm{~m}$ depth. Nauplii were more abundant during 1981 in all depth strata ( $p<0.00001)$. These observations suggest that copepod spawning and seasonal development was more advanced as the season progressed in 1981 compared to 1980.

Comparison of differences in Calanus finmarchicus copepodites among years reveals significant differences in both the relative rates of copepodite development and in absolute abundances. Direct observations can be made among years for 0.165 and $0.333 \mathrm{~mm}$ mesh samples at various times (Table 4). Relative stage densities of C. finmarchicus copepodites from 23 April to 9 May 1979 compared with 2 to 9 May 1981 for large mesh samples indicate that development was more advanced in 1981 (Kolmogorov-Smirnov test, $\mathrm{p}<0.01$ ). However, this comparison must be qualified, because stages CI to $C I I$ were not sampled by the $0.505 \mathrm{~mm}$ mesh nets used in 1981 (Anderson \& Warren in press). Comparing $0.165 \mathrm{~mm}$ mesh samples in late May 1980 and 1981. development of copepods in 1980 significantly lagged that of 1981 by 1 stage (Kolmogorov-Smirnov test, $\mathrm{p}<0.01$ ). This was supported by the $0.333 \mathrm{~mm}$ mesh data. In both cases stage CIII was dominant in 1980 and stage CIV in 1981 at the time of sampling. The differences between late May 1980 and 1981 were also found among other calanoid species for which stage abundance data are available; C. hyperboreus and Microcalanus spp. were also more advanced in 1981.
By mid-July to early August stage CV dominated in all years from 1979 to 1982 . Kolmogorov-Smirnov tests among years demonstrated that Calanus finmarchicus copepodites from $0.165 \mathrm{~mm}$ mesh samples were more advanced in 1979 than in 1982 ( $p<0.01$, Table 4). CV dominated both years, but CIV was relatively less abundant and CVI was more abundant in 1979 than in 1982. Further comparisons of copepodite stage differences based on $0.333 \mathrm{~mm}$ mesh samples demonstrated no significant differences between 1980 and 1982, but both years were significantly different from 1981 $(\mathrm{p}<0.01)$. CIV was relatively less abundant in 1981 compared to 1980 and 1982 (Table 4). Therefore, development of $C$. finmarchicus was more advanced in 1981 than in 1980 and 1982. Given that the time of sampling was identical for 1981 and 1982 and earlier in 1979 than in 1982, these differences in copepodite stages would have resulted from an earlier spawning time, more rapid development rate, or both. The earlier sampling data in 1980 compared to 1981 (7 d) may have contributed to the difference between these years.

A direct comparison could not be made between 1979 and 1980 or 1981 data as mesh sizes were not the same. However, CIV:CV catch ratios were 0.113 in 1979 (0.165 mm mesh data) and 0.026 in $1981(0.333 \mathrm{~mm}$ mesh data), indicating that development in 1979 lagged that of 1981. Given these comparisons it appears that copepodite development was most advanced in 1981, followed by 1979 , followed in turn by 1980 and 1982 , which were not different form each other.

These observations of relative stage differences in summer (July to August) are supported by comparisons earlier in the season. During late May copepodite development was more advanced in 1981 than in 1980

Table 4. Calanus finmarchicus. Comparison of copepodite stage densities (no. $\mathrm{m}^{-3}$ ) in different years for waters $\leq 400 \mathrm{~m}$ depth on Flemish Cap, from $0.165 \mathrm{~mm}$ and $0.333 \mathrm{~mm}$ mesh samples

\begin{tabular}{|c|c|c|c|c|c|c|c|c|c|c|c|c|}
\hline \multirow[t]{2}{*}{ Date } & \multicolumn{6}{|c|}{ Copepodite density $(0.333 \mathrm{~mm}$ mesh $)$} & \multicolumn{6}{|c|}{ Copepodite density (0.165 mm mesh) } \\
\hline & C I & C II & C III & C IV & C V & C VI & CI & C II & C III & C IV & C V & $\mathrm{C}$ VI \\
\hline Apr 23-May 9, 1979 & 8.6 & 13.9 & 10.8 & 7.9 & 6.8 & 49.5 & & & & & & \\
\hline May 2-9, 1981 & - & - & 36.6 & 63.1 & 8.2 & 7.5 & & & & & & \\
\hline $\begin{array}{c}\text { May } 21-31,1980 \\
\text { vs }\end{array}$ & 1.2 & 8.5 & 35.8 & 20.2 & 6.1 & 25.1 & 13.7 & 25.7 & 34.8 & 14.4 & 3.6 & 16.7 \\
\hline May $22-27,1981$ & - & 3.2 & 50.3 & 267.2 & 119.5 & 22.2 & 10.4 & 7.3 & 57.0 & 200.3 & 91.3 & 17.5 \\
\hline Jul $10-14,1979$ & & & & & & & 6.9 & 9.3 & 9.4 & 30.7 & 277.8 & 54.8 \\
\hline Aug 1-3, 1982 & & & & & & & 3.8 & 1.5 & 5.8 & 81.3 & 355.1 & 4.9 \\
\hline $\begin{array}{c}\text { Jul } 20-29,1980 \\
\text { vs }\end{array}$ & - & 3.4 & 10.5 & 14.4 & 55.2 & 8.7 & & & & & & \\
\hline Aug $1-4,1981$ & - & - & 2.3 & 2.1 & 74.8 & 17.8 & & & & & & \\
\hline Aug $1-3,1982$ & - & - & 5.1 & 93.4 & 274.9 & 6.3 & & & & & & \\
\hline
\end{tabular}


which was still true in July to August. At the beginning of May development was again more advanced in 1981 than in 1979 and this was still true in summer. The samples are distributed unevenly in time, but overall support the fact that copepodite development differed among years, beginning early in the season.

Comparison of copepod abundances among years must be done with caution due to possible differences among years in the time of spawning, the temperature dependent rate of copepod development and stagedependent mortalities. Copepod densities were greater in 1981 for April to May compared to 1979 and 1980 (Table 5). This was true for both Calanus finmarchicus and other copepods for each strata. All comparisons indicated these differences were significant except for C. finmarchicus in late May 1980 vs 1981 for waters $\leq 200 \mathrm{~m}$ (all meshes) and waters $>400 \mathrm{~m}$ for $0.080 \mathrm{~mm}$ mesh data only (Tables 6 and 7). For July to August

Table 5. Comparison of mean densities (no $\mathrm{m}^{-3}$ ) of Calanus finmarchicus and other copepods among years on Flemish Cap within different depth strata for $0.165 \mathrm{~mm}$ and $0.333 \mathrm{~mm}$ mesh samples

\begin{tabular}{|c|c|c|c|c|c|c|}
\hline \multirow[t]{2}{*}{ Species/group } & \multirow[t]{2}{*}{ Date } & \multicolumn{4}{|c|}{ Strata (m) } & \multirow[b]{2}{*}{ Total } \\
\hline & & $\leq 200$ & $201-400$ & $\leq 400$ & $>400$ & \\
\hline \multicolumn{7}{|c|}{ Mesh size $=0.165 \mathrm{~mm}$} \\
\hline \multirow[t]{4}{*}{ C. finmarchicus } & $\begin{array}{c}\text { May } 21-31,1980 \\
\text { vs }\end{array}$ & 72.0 & 90.3 & 86.2 & 179.1 & 138.3 \\
\hline & May 22-27, 1981 & 262.9 & 395.1 & 367.3 & 288.7 & 325.1 \\
\hline & Jul 10-14, 1979 & 413.3 & 367.1 & 383.9 & 271.2 & 366.6 \\
\hline & Aug 1-3, 1982 & 348.5 & 475.1 & 447.0 & 210.8 & 413.2 \\
\hline \multirow[t]{4}{*}{ Other copepods } & May 21-31, 1980 & 100.2 & 219.6 & 193.0 & 265.4 & 233.7 \\
\hline & May $22-27,1981$ & 1367.2 & 741.1 & 872.9 & 660.7 & 759.1 \\
\hline & Jul 10-14, 1979 & 1166.2 & 832.5 & 953.9 & 312.9 & 855.3 \\
\hline & Aug 1-3, 1982 & 504.0 & 376.0 & 404.4 & 179.9 & 372.3 \\
\hline \multicolumn{7}{|c|}{ Mesh size $=0.333 \mathrm{~mm}$} \\
\hline \multirow{7}{*}{ C. finmarchicus } & $\begin{array}{c}\text { vs } \\
\text { May } 2-9,1981^{\circ}\end{array}$ & 191.7 & 237.3 & 225.9 & 188.2 & 207.7 \\
\hline & $\begin{array}{c}\text { May } 21-31,1980 \\
\text { vs }\end{array}$ & 245.1 & 75.3 & 95.9 & 129.5 & 109.7 \\
\hline & May 22-27, 1981 & 324.3 & 505.8 & 467.6 & 337.1 & 396.1 \\
\hline & $\begin{array}{c}\text { Jul } 10-14,1979^{\cdots} \cdot \\
\text { vs }\end{array}$ & 343.5 & 305.1 & 319.1 & 225.4 & 304.7 \\
\hline & Jul $20-29,1980$ & 157.0 & 59.8 & 85.1 & 57.6 & 73.1 \\
\hline & Aug $1-4,1981$ & 168.3 & 76.0 & 96.5 & 37.1 & 90.5 \\
\hline & Aug $1-3,1982$ & 267.8 & 411.2 & 379.3 & 223.6 & 357.1 \\
\hline \multirow[t]{8}{*}{ Other copepods } & Apr 23-May 9, 1979 & 35.4 & 61.9 & 53.6 & 73.3 & 63.6 \\
\hline & May $2-9,1981^{\circ}$ & 96.2 & 162.3 & 145.8 & 105.8 & 126.4 \\
\hline & May 21-31, 1980 & 21.4 & 54.2 & 50.3 & 50.7 & 50.4 \\
\hline & $\begin{array}{c}\text { vs } \\
\text { May } 22-27,1981\end{array}$ & 76.7 & 139.3 & 126.1 & 110.8 & 117.7 \\
\hline & $\begin{array}{c}\text { Jul } 10-14,1979 \cdots \\
\text { vs }\end{array}$ & 231.3 & 165.1 & 189.2 & 62.1 & 169.6 \\
\hline & $\begin{array}{c}\text { Jul } 20-29,1980 \\
\text { vs }\end{array}$ & 20.1 & 16.0 & 17.1 & 23.2 & 19.8 \\
\hline & Aug 1-4, 1981 & 31.3 & 29.0 & 29.5 & 39.9 & 30.6 \\
\hline & Aug $1-3,1982$ & 37.9 & 48.4 & 46.1 & 33.9 & 44.3 \\
\hline
\end{tabular}


there were no differences among years from $0.165 \mathrm{~mm}$ mesh samples for the 2 highest years, 1979 and 1982. However, there were significant differences among $0.333 \mathrm{~mm}$ mesh data from 1980, 1981 and 1982 in all strata for $C$. finmarchicus and for waters in the 201 to $400 \mathrm{~m}$ and $\leq 400 \mathrm{~m}$ strata for copepods other than $C$. finmarchicus (Table 8). These comparisons demonstrate that densities of $C$. finmarchicus were lowest in 1980 and 1981 during July to August while 1979 and 1982 were highest. Copepods other than C. finmar-

Table 6. Summary of non-parametric analyses of differences among years for copepods from April 23 to May 9, 1979 vs May 2 to 9,1981 within different depth strata for $0.333 \mathrm{~mm}$ and $0.505 \mathrm{~mm}$ mesh samples

\begin{tabular}{|lllll|}
\hline \multirow{2}{*}{ Species/group } & \multicolumn{5}{c}{ Strata (m) } \\
& $\leq 200$ & $201-400$ & $\leq 400$ & $>400$ \\
\hline Calanus & $2.4749^{\circ}$ & 3.6348 & 4.3737 & 1.7266 \\
finmarchicus & $0.0133^{\cdots}$ & 0.0003 & 0.0000 & 0.0842 \\
Other & 2.1920 & 3.4520 & 4.2569 & 1.9671 \\
copepods & 0.0284 & 0.0004 & 0.0000 & 0.0492 \\
Total & 2.3335 & 3.9132 & 4.7244 & 1.7782 \\
copepods & 0.0196 & 0.0001 & 0.0000 & 0.0754 \\
$\begin{array}{l}\text { - Wilcoxon Z-values } \\
\therefore \text { Probability }\end{array}$ & & & \\
\hline
\end{tabular}

chicus were significantly lower in 1980 than in the other 3 yr. Differences among years for copepod densities were similar to those reported for plankton biomass of the entire plankton community, demonstrating the important contribution of copepods to total biomass on Flemish Cap.

\section{Predictions of peak spawning of Calanus finmarchicus}

Surface water temperatures over Flemish Cap historically increase from a winter low of $3.3 \pm 0.03^{\circ} \mathrm{C}$ in February to a maximum of $12.7 \pm 0.6^{\circ} \mathrm{C}$ in August (Anderson 1984). The period of maximum rate of increase in temperature occurs during June each year. Mean surface water temperatures were significantly different during the spring heating period. The coldest year was 1980 and the warmest years were 1979 and 1981. Temperatures in 1980 were not significantly different from the long-term mean, while during April and June 1979, and May and June 1981, temperatures were significantly higher than the long-term mean (Anderson 1984).

Predictions of the time of peak spawning for Calanus finmarchicus in 1980 and 1981 are based on back calculations, using temperature-dependent Bĕlehrádek equations, from observations at the same time during

Table 7. Summary of non-parametric analyses of differences among years for copepods from May 21 to 31,1980 vs May 22 to 27, 1981 within different depth strata and for different mesh size samples. ns: not significant

\begin{tabular}{|c|c|c|c|c|c|}
\hline \multirow[t]{2}{*}{ Species/group } & \multirow{2}{*}{$\begin{array}{l}\text { Sample mesh } \\
\qquad(\mathrm{mm})\end{array}$} & \multicolumn{4}{|c|}{ Strata $(\mathrm{m})$} \\
\hline & & $\leq 200$ & $201-400$ & $\leq 400$ & $>400$ \\
\hline \multirow[t]{3}{*}{ Calanus finmarchicus } & 0.080 & ns & $\begin{array}{r}-1.9091^{\circ} \\
0.0563^{\circ}\end{array}$ & $\begin{array}{r}-2.4530 \\
0.0142\end{array}$ & ns \\
\hline & 0.165 & $\mathrm{~ns}$ & $\begin{array}{r}-3.6442 \\
0.0003\end{array}$ & $\begin{array}{r}-4.1174 \\
0.0000\end{array}$ & $\begin{array}{l}1.6462 \\
0.0997\end{array}$ \\
\hline & 0.333 & ns & $\begin{array}{l}4.9519 \\
0.0000\end{array}$ & $\begin{array}{l}5.2448 \\
0.0000\end{array}$ & $\begin{array}{r}-3.1196 \\
0.0018\end{array}$ \\
\hline \multirow[t]{3}{*}{ Other copepods } & 0.080 & $\begin{array}{r}-2.1651 \\
0.0304\end{array}$ & $\begin{array}{r}-3.7745 \\
0.0002\end{array}$ & $\begin{array}{r}-4.4960 \\
0.0000\end{array}$ & $\begin{array}{r}-5.2726 \\
0.0000\end{array}$ \\
\hline & 0.165 & $\begin{array}{r}-2.1651 \\
0.0304\end{array}$ & $\begin{array}{r}-3.6879 \\
0.0002\end{array}$ & $\begin{array}{r}-4.2997 \\
0.0000\end{array}$ & $\begin{array}{l}3.6670 \\
0.0002\end{array}$ \\
\hline & 0.333 & $\begin{array}{r}-2.1651 \\
0.0304\end{array}$ & $\begin{array}{l}4.0605 \\
0.0000\end{array}$ & $\begin{array}{l}4.4277 \\
0.0000\end{array}$ & $\begin{array}{r}-3.3173 \\
0.0009\end{array}$ \\
\hline \multirow[t]{3}{*}{ Total copepods } & 0.080 & $\begin{array}{r}-2.1651 \\
0.0304\end{array}$ & $\begin{array}{r}-3.4012 \\
0.0007\end{array}$ & $\begin{array}{r}-4.1748 \\
0.0000\end{array}$ & $\begin{array}{r}-4.3938 \\
0.0000\end{array}$ \\
\hline & 0.165 & $\begin{array}{r}-2.1651 \\
0.0304\end{array}$ & $\begin{array}{r}-3.6879 \\
0.0002\end{array}$ & $\begin{array}{r}-4.3909 \\
0.0000\end{array}$ & $\begin{array}{l}3.5989 \\
0.0003\end{array}$ \\
\hline & 0.333 & ns & $\begin{array}{l}5.0014 \\
0.0000\end{array}$ & $\begin{array}{l}5.2258 \\
0.0000\end{array}$ & $\begin{array}{r}-4.3938 \\
0.0000\end{array}$ \\
\hline $\begin{array}{l}\text { - Wilcoxon Z-values } \\
\text { Probability }\end{array}$ & & & & & \\
\hline
\end{tabular}


Table 8. Non-parametric analyses of differences among years for copepods during July to August 1979 to 1982 within different depth strata for $0.333 \mathrm{~mm}$ mesh samples [1-way ANOVA on, rank scores for F-value, p-levels and Duncans multiple range (DMR) test]. Other copepods refers to those other than Calanus finmarchicus. Years refer to the following dates: July 20 to 29, 1980 , August 1 to 4, 1981, August 1 to 3, 1982. ns: not significant

\begin{tabular}{|c|c|c|c|c|c|c|c|c|}
\hline \multirow[t]{3}{*}{ Species/group } & \multicolumn{8}{|c|}{ Strata $(m)$} \\
\hline & \multicolumn{2}{|c|}{$\leq 200$} & \multicolumn{2}{|c|}{$201-400$} & \multicolumn{2}{|c|}{$\leq 400$} & \multicolumn{2}{|c|}{$>400$} \\
\hline & $\begin{array}{l}\text { F-value } \\
\text { p-level }\end{array}$ & $\begin{array}{l}\text { DMR Test } \\
(\mathrm{p}<0.05)\end{array}$ & $\begin{array}{l}\text { F-value } \\
\text { p-level }\end{array}$ & $\begin{array}{l}\text { DMR Test } \\
(\mathrm{p}<0.05)\end{array}$ & $\begin{array}{l}\text { F-value } \\
\text { p-level }\end{array}$ & $\begin{array}{l}\text { DMR Test } \\
(\mathrm{p}<0.05)\end{array}$ & $\begin{array}{l}\text { F-value } \\
\text { p-level }\end{array}$ & $\begin{array}{c}\text { DMR Test } \\
(\mathrm{p}<0.05)\end{array}$ \\
\hline C. finmarchicus & ns & - & $\begin{array}{l}29.99 \\
0.0001\end{array}$ & $\begin{array}{l}1982 \\
1981 \\
1980\end{array}$ & $\begin{array}{l}17.05 \\
0.0001\end{array}$ & $\begin{array}{l}1982 \\
1981 \\
1980\end{array}$ & $\begin{array}{l}4.24 \\
0.0292\end{array}$ & $\begin{array}{l}1982 \\
1980 \\
1981\end{array}$ \\
\hline Other copepods & ns & - & $\begin{array}{l}9.13 \\
0.0005\end{array}$ & $\begin{array}{l}1982 \\
1981 \\
1980\end{array}$ & $\begin{array}{l}9.12 \\
0.0004\end{array}$ & $\begin{array}{l}1982 \\
1981 \\
1980\end{array}$ & ns & \\
\hline Total copepods & ns & - & $\begin{array}{l}31.60 \\
0.0001\end{array}$ & $\begin{array}{l}1982 \\
1981 \\
1980\end{array} \mid$ & $\begin{array}{l}17.32 \\
0.0001\end{array}$ & $\begin{array}{l}1982 \\
1981 \\
1980\end{array}$ & $\begin{array}{l}4.26 \\
0.0288\end{array}$ & $\begin{array}{l}1982 \\
1981 \\
1980\end{array}$ \\
\hline
\end{tabular}

late May each year (Day 145). By late May, peak spawning had past and all regions of Flemish Cap were dominated by a single copepodite stage: stage CIII in 1980 and CIV in 1981. Back calculations predict that peak spawning occurred 36.5 and $38.2 \mathrm{~d}$ before Day 145 in 1980 and 1981, respectively (Fig. 6). Thus, in spite of a difference in copepodite stage dominance in late May, predictions of peak spawning are not different (18 April 1980 and 17 April 1981). This indicates that most of the observed interannual difference in stage composition can be explained by differences in temperature dependent development rather than an earlier spawning time.

Comparison of Calanus finmarchicus development to that predicted from long-term mean temperatures for Flemish Cap gives some insight into conditions on the Cap during the 3 yr surveyed (1979 to 1981). Develop-

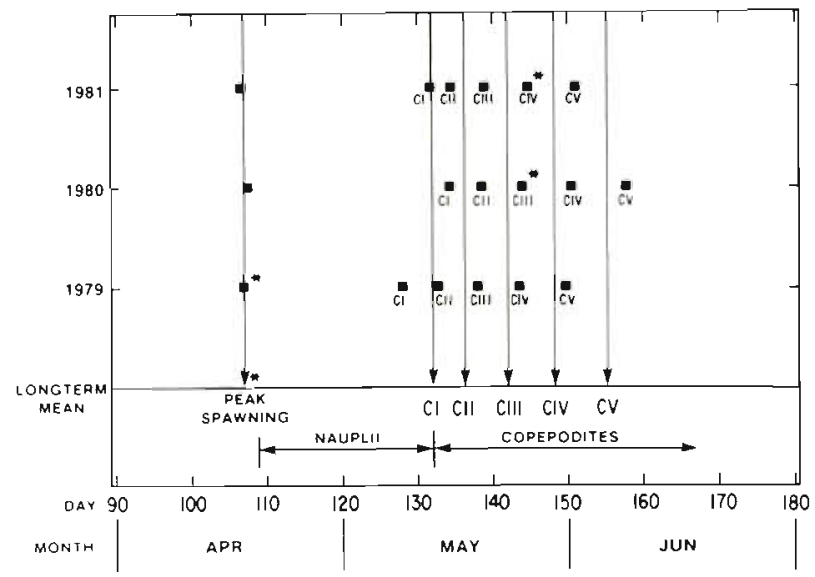

Fig. 6. Calanus finmarchicus. Development times predicted in different years based on temperature-dependent Bělehrádek equations. $\mathrm{Cl}$ refers to copepodite stage $\mathrm{Cl}$, etc. Asterisk: date from which projections of stage development were made ment of C. finmarchicus based on long-term temperatures for surface waters overlying Flemish Cap at $\leq 200 \mathrm{~m}$ were scaled relative to an estimated date of peak spawning on Day 107 (15 April). Development during 1979 to 1981 was compared to that predicted from long-term temperatures (Fig. 6). Predictions for 1979 were also scaled to Day 107 as there were no postpeak spawning observations for that year. These comparisons indicate that development of $C$. finmarchicus was slower in 1980 than that predicted from the longterm mean, but faster in both 1979 and 1981. In 1980 nauplii development was slowed in April and by stage CI development lagged the long-term prediction of copepod development by $2.3 \mathrm{~d}$. For stages CII to $\mathrm{CV}$ this lag then remained constant. In 1981 development through all nauplii stages to $\mathrm{CI}$ equalled that predicted for the long-term mean. However, development rate from $\mathrm{CI}$ to $\mathrm{CV}$ during May began to increase compared to the long-term mean and by stage CV preceded it by $3.8 \mathrm{~d}$. In 1979 it is estimated that development was faster than the long-term mean for both nauplii and copepodite stages. CI was $4 \mathrm{~d}$, and CV $5.4 \mathrm{~d}$ faster than predicted by long-term mean temperatures.

\section{DISCUSSION}

In the invertebrate zooplankton community on Flemish Cap, Calanus finmarchicus numerically dominated the larger mesh samples (0.333 and $0.505 \mathrm{~mm})$, was the second most abundant species in small mesh samples (0.165 mm), and was always dominant in terms of biomass. Such dominance of $C$. finmarchicus has been reported throughout much of the NW Atlantic. Specific areas include Davis Strait (Huntley et al. 1983), seas off East and West Greenland, Irminger Sea and Labrador 
Sea (Bainbridge \& Corlett 1968), Scotian Shelf (Tremblay \& Roff 1983) and on Georges Bank (Davis 1987). Previous investigations carried out over several years on Flemish Cap demonstrated copepods dominated the plankton from March to July constituting 88 to $98 \%$ of the total zooplankton by number (Konstantinov et al. 1985). C. finmarchicus numerically ranged from 39 to $66 \%$ while Oithona similis ranked second, ranging from 28 to $57 \%$ of the total zooplankton. These results were for a $30 \mathrm{~cm}$ Juday net using no. 38 gauze $(0.500$ $\mathrm{mm}$ ) and are similar to results reported here using the coarser mesh nets.

The timing of spring Calanus finmarchicus spawning reported in this study was mid-April. Peak biomass from 0.165 and $0.333 \mathrm{~mm}$ mesh nets occurred during sampling in late May. These observations are supported by previous investigations on Flemish Cap (Vladimirskaya 1967, Konstantinov et al. 1985). Both the time of spring spawning and subsequent peak plankton biomass occurred approximately 1 mo later on Flemish Cap than in shelf waters to the west and south. On Georges Bank spawning of C. finmarchicus appears to occur in March (Fig. 24.3 in Davis 1987). This also appears to be true of Browns Bank on the southern Scotian Shelf, as McLaren \& Corkett (1986) report spawning of $C$. finmarchicus had not occurred by late February whereas nauplii were abundant by mid-April. Similarly, C. finmarchicus spawning was reported to begin in late February or March on the southern Grand Bank, and by late March nauplii constituted 80 to $90 \%$ of the population (Vladimirskaya 1967), indicating that mass spawning occurred during March. Samples taken between 17 and 31 March 1960 and between 6 April and 2 May 1958 indicated that C. finmarchicus spawning had just started on Flemish Cap, was intensively underway in the Labrador Current $\left(47^{\circ} \mathrm{N}\right)$, and was mostly finished on the northern Grand Bank $\left(57^{\circ} \mathrm{N}\right)$ with the plankton being dominated by nauplii at that time (Vladimirskaya 1967).

Therefore, Flemish Cap is characterized as a distinct marine system dominated by Calanus finmarchicus which spawns about 1 mo later than on the Grand Banks, Scotian Shelf and Georges Bank. Peak plankton biomass probably occurs 1 mo later as well. The timing of C. finmarchicus spring spawning is known to be closely linked to the initiation of the spring bloom (Krauss \& Trahms 1983), and the magnitude of production is dependent on the size of overwintering stock of copepods and the concentration of spring phytoplankton (Runge 1988). This would indicate that the spring bloom does not start until April on Flemish Cap, which is supported by chlorophyll observations made during March to May 1979 to 1981 on Flemish Cap (J. Anderson unpubl.). It is noteworthy that among year differences in abundance and copepodite stages persisted from early May to August, through the complete development of $C$. finmarchicus from spawning to stage $\mathrm{CV}$ diapause. This indicates the importance of initial conditions during April and May in determining the total production and development of $C$. finmarchicus within a year.

This study indicates that there were significant differences in the rate of development among years, but not necessarily in the time of peak spawning. When food is not limiting then development rate of Calanus finmarchicus will vary directly due to water temperatures (Landry 1983, Corkett et al. 1986). Differences in water temperatures will be mostly a function of the seasonal heating cycle due to increased solar radiation, but also may vary with advective mixing of cold (Labrador Current) or warm (North Atlantic Current) waters onto Flemish Cap. Analysis of the formation of the mixed layer depth on Flemish Cap indicated measureable differences during 1979 to 1981 , with MLD, on average, much deeper early in the year in March and April 1979. However, this did not reduce the surface warming of water in 1979 as temperatures were always high (J. Anderson, J. Booth, R. Keeley, unpubl.).

Advective processes that result in water mass replacement may cause significant movements of plankton on or off Flemish Cap. However, previous studies indicate significant changes in water mass characteristics do not occur on a year-to-year basis. Instead, changes occur cyclically over 3 to 5 yr intervals (Hayes et al. 1977, Keeley 1982). These cycles appear to result from atmospheric forcing of the subarctic gyre and its subsequent interaction with the Labrador and North Atlantic Currents (Hayes et al. 1977). The 3 yr of this study, 1979 to 1981 , were characterized by a period of higher temperatures and salinities relative to longterm mean conditions (Keeley 1982). Therefore, there was no apparent shift in oceanographic conditions that might occur coincident with a switch from warm-saline to cold-fresh years.

Flemish Cap waters represent a mixture of Labrador Current and North Atlantic Current water types (Hayes et al. 1977. Keeley 1982). The circulation on Flemish Cap is characterized by a weak anticyclonic circulation (ca 3 to $5 \mathrm{~cm} \mathrm{~s}^{-1}$ residual circulation) that can be disrupted by storms (Hill et al. 1975, Hayes et al. 1977 Ross 1980, 1981, Kudlo et al. 1984). Loder et al. (1988) reported a mean annual recirculation time of 67 to $78 \mathrm{~d}$ for near-surface waters along the $400 \mathrm{~m}$ isobath and a mean residence time of 32 to $40 \mathrm{~d}$ for near-surface waters within the $400 \mathrm{~m}$ isobath. They concluded there is sufficient residency time to be favourable to biological processes. In addition, the gyre tends to become more stable with the transition from winter to summer conditions (Kudlo et al. 1984). Therefore, residence 
time would be expected to increase with the seasonal formation of the pycnoline, which is noticeably developed by May (Drinkwater \& Trites 1986). The existing oceanographic information supports the fact that the waters over Flemish Cap are retained for sufficient periods of time for the growth and maintenance of copepod populations.

It is expected that interannual differences observed in both the rate of copepod development and the magnitude of spring spawning would have a significant effect on larval fish feeding. It has long been postulated that the timing of the spring bloom in temperate oceans will have a significant effect on larval fish survival and ultimately fish recruitment (Cushing 1975). However, it has been difficult to demonstrate such a direct relationship. More recently, Runge (1988) hypothesized that copepods will act as a direct link between phytoplankton and fisheries variability in temperate marine ecosystems dominated by larger copepods. Runge emphasized differences in the timing and magnitude of spring primary production acting through copepod seasonal dynamics which will effect differences in larval fish survival among years.

This study demonstrates that significant differences occurred in Calanus finmarchicus development rate among years, even though the date of peak spawning was the same. Previously it has been implied that survival of larval fish is directly linked to the onset of spring production from which other processes follow (Cushing 1975). However, the environment can directly effect changes in the timing of the spring production cycle of copepods among years, independent of the timing of the onset of the spring bloom. It is hypothesized that such inter-annual differences in the rate of copepod development will have a significant effect on larval fish feeding, growth and survival. In this way the copepods act as a direct link between environmental variation and larval fish survival, as proposed by Runge (1988). When copepod development proceeds too quickly then nauplii, the primary food source of larval fish, would be available for a shorter period of time. This could have a negative impact on larval fish growth and survival. It is important to emphasize that the difference reported here in copepod development among years is a difference in rates. The absolute difference of one copepodite stage observed in late May in 1980 vs 1981 reflects these differences in rates of change which occurred throughout the spring period. This observation is supported by the eggs and nauplii which show similar differences in the rate of development for the earlier copepod stages.

In addition, changes in the magnitude of production will have a significant effect on growth and survival when larval fish prey is limiting. Density of Calanus finmarchicus in early May was $2.4 \times$ higher in 1981 than in 1979 , and in late May was $4.3 \times$ higher than in 1980 for waters $\leq 400 \mathrm{~m}$ depth. From mid-July to the first week of August density varied by a factor of 4.5 in 1979 to 1982 . Plankton volume measured during this same period in 1978,1980 to 1982 ranged from 0.21 to $0.53 \mathrm{ml} \mathrm{m}^{-3}$, a factor of $2.6 \times$. These differences were statistically different and may have had a significant effect on larval fish survival. However, it remains to be demonstrated that such differences in copepod development rate and production do have a significant effect on the feeding, growth and survival of these fish larvae.

Acknowledgements. Many people contributed to the collection and processing of the samples used in this study. Technical assistance through much of the study was provided by $C$. Fitzpatrick. R. Penney and T. Shears. M. Foy contributed knowledgeably to the taxonomic classifications. Key contributors to the Flemish Cap Project include S. Akenhead and G. Lilly, to whom I attribute constructive input and encouragement throughout the study. For thorough and inspiring reviews I thank J. Runge, M. Paranjape and 2 anonymous reviewers.

\section{LITERATURE CITED}

Anderson, J. T. (1984). Early life history of redfish (Sebastes spp.) on Flemish Cap. Can. J. Fish. Aquat. Sci. 41: $1106-1116$

Anderson, J. T. (1988). A review of size dependent survival during pre-recruit stages of fishes in relation to recruitment. J. NW Atl. Fish. Sci. 8: 55-66

Anderson, J. T., Warren, W. G. (1990). Comparison of catch rates among small and large mesh samples for Calanus finmarchicus copepodite stages. Can. J. Fish. Aquat. Sci. (in press)

Bainbridge, V., Corlett, J. (1968). The zooplankton of the Norwestlant surveys. Spec. Publs int. Commn NW Atlant. Fish No. 7: 101-122

Bainbridge, V., McKay, B. J. (1968). The feeding of cod and redfish larvae. Spec. Publs int. Commn NW Atlant. Fish 7 : $187-217$

Brown, M. B., Forsythe, A. B. (1974). Robust tests for the equality of variances. J. Am. statist. As. 69: 364-367

Corkett, C. J., McLaren, I. A., Sevigny, J. M. (1986). The rearing of the Calanoid copepods Calanus finmarchicus (Gunnevus), C. glacialis Jaschnov and C. hyperboreus Kroyer with comment on the equiportional rule. In: $G$. Schriever, Schminke, H. K., Shih, C. T. (eds.) Proc. $2^{\text {nd }}$ Intl. Conf. on Copepoda. Syllogeus 58: 539-546

Cushing, D. H. (1975). Marine ecology and fisheries. Cambridge Univ. Press. Cambridge

Cushing, D. H. (1989). A difference in structure between ecosystems in strongly stratified waters in those that are only weakly stratified. J. Plankton Res. 11: 1-13

Davis, C. S. (1987). Zooplankton life cycles. In: Backus, R. H., Bourne, D. W. (eds.) Georges Bank, MIT Press, Cambridge, p. 256-267

Drinkwater, K. F., Trites, R. W. (1986). Monthly mean temperature and salinity in the Grand Banks region. Can. Tech. Rep. Fish. Aquat. Sci. 1450: 1-111

Foy, M., Anderson, J. T. (1986). Marine plankton computer codes for the Northwest Atlantic Fisheries Centre. Can. Data Rep. Fish. Aquat. Sci. No. 585 
Hayes, R. M., Mountain, D. G., Wolford, T. C. (1977). Physical oceanography and the abiotic influence on cod recruitment on Flemish Cap. Res. Doc. int. Commn NW Atlant. Fish.

Lilly, G. R. (1987). Synopsis of research related to recruitment of Atlantic cod (Gadus morhua) and Atlantic Redfishes (Sebastes sp.) on Flemish Cap. NW Atl. Fish. Org. Sci. Coun. Stud. 11: 109-122

Loder, J. W., Ross, C. K., Smith, P. C. (1988). A space- and time-scale characterization of circulation and mixing over submarine banks, with application to the northwestern Atlantic continental shelf. Can. J. Fish. Aquat. Sci. 45: $1860-1885$

McLaren, I. A., Corkett, C. J. (1986). Life cycles and production of two copepods on the Scotian Shelf, eastern Canada. In: Schriever, G., Schminke, H. K., Shih, C.-T. (eds.) Proc. of $2^{\text {nd }}$ Intl. Conf. on Copepoda, Syllogeus 58: 362-368

Ross, C. K. (1980). Moored current meter data from Flemish Cap January-July, 1979, NW Atl. Fish. Org. SCR Doc. 80/ LX/128. Ser. No. N200: 1-13

Ross, C. K. (1981). Drift of satellite-tracked buoys on Flemish Cap, 1979-1980. NW Atl. Fish. Org. Sci. Coun. Stud. 1: $47-50$

Runge, J. A. (1988). Should we expect a relationship between primary production and fisheries? The role of copepod dynamics as a filter of trophic variability. Hydrobiol. 167/ 168: $61-71$

SAS (Statistical Analysis System) (1985). SAS user's guide: statistics version 5 edition. Statistical analysis Institute Inc., Cary, North Carolina

Siegel, S. (1956). Non-parametric statistics for the behavioural sciences. McGraw Hill, Toronto

This article was presented by Professor R. L. Haedrich, St. John's, Newfoundland, Canada
Sokal, R. R., Rohlf, F. J. (1969) Biometry. W. H. Freeman and Co. San Francisco

Smith, P. E., Richardson, S. L. (1977). Standard techniques for pelagic fish egg and larval surveys. FAO Tech. Pap. No. 175

Tremblay, M. J. (1981). Zooplankton community structure, biomass and production of the Scotian Shelf, with special reference to Emerald Bank. M. Sc. thesis, University of Guelph

Tremblay, M. J., Roff, J. C. (1983). Production estimates for Scotian Shelf copepods based on mass specific P/B ratios. Can. J. Fish. Aquat. Sci. 40: 749-753

Van Guelpen, L., Markle, D. F., Duggan, D. J. (1982). An evaluation of accuracy, precision, and speed of several zooplankton subsampling techniques. J. Cons. int. Explor. Mer 40: 226-236

Vadimirskaya, E. V. (1967). Seasonal population dynamics of Calanus finmarchicus (Gunner) in the northwestern Atlantic, 1958-1961. Res. Bull. int. Commn NW Atlant. Fish. 4: $41-52$

Webster, I., Anderson, J. T. (1987). A model for simulating the towing performance of the bongo sampler. Deep-Sea Res. 34: 1277-1291

Williams, R., Conway, D. V. P. (1988). Vertical distribution and seasonal numerical abundance of the Calanidae in oceanic waters to the south-west of the British Isles. Hydrobiologia 167/168: 259-266

Williams, R., Conway, D. V. P., Collins, N. R. (1987). Vertical distributions of eggs, nauplii and copepodites of Calanus helgolandicus (Copepoda: Crustacea) in the Celtic Sea. Mar. Biol. 96: 247-252

Manuscript first received: February 2, 1990

Revised version accepted: July 17, 1990 